Review Article

\title{
A Literature Survey on Wireless Power Transfer for Biomedical Devices
}

\author{
Reem Shadid (iD) and Sima Noghanian \\ Electrical Engineering Department, University of North Dakota, Grand Forks, ND 58203, USA \\ Correspondence should be addressed to Reem Shadid; reem.shadid@und.edu
}

Received 27 December 2017; Revised 26 February 2018; Accepted 6 March 2018; Published 12 April 2018

Academic Editor: Giuseppina Monti

Copyright (c) 2018 Reem Shadid and Sima Noghanian. This is an open access article distributed under the Creative Commons Attribution License, which permits unrestricted use, distribution, and reproduction in any medium, provided the original work is properly cited.

\begin{abstract}
This paper provides a review and survey of research on power transfer for biomedical applications based on inductive coupling. There is interest in wireless power transfer (WPT) for implantable and wearable biomedical devices, for example, heart pacemaker or implantable electrocardiogram (ECG) recorders. This paper concentrates on the applications based on near-field power transfer methods, summarizes the main design features in the recent literature, and provides some information about the system model and coil optimization.
\end{abstract}

\section{Introduction}

Implantable medical devices such as cochlear implants, cardiac defibrillators, electrocardiogram (ECG) implanted recorders, and pacemakers play an important role in monitoring treatment of various diseases. These devices interact with physiological processes including sensing, drug delivery, and stimulation, to monitor or influence their progression. However, minimizing the size of implanted devices makes them less invasive to human body and decreases the surgical complexity in order to install them easily inside the body. While recent progress in microfabrication has dramatically minimized the size of electronic and mechanical components, electrochemical energy storage has been much slower to miniaturize. In most existing devices, the battery constitutes the bulk of the implant [1]. In addition, surgical procedures for replacing the batteries and the risk of leakage are the major disadvantages of using them [2]. Wireless power transfer (WPT) is used to transmit power to help avoid these problems.

In WPT, an external power source will transmit energy to the implanted power receivers. Although many techniques, such as optical and ultrasound methods, have been launched to transfer power wirelessly, wireless powering through radio-frequency $(\mathrm{RF})$ electromagnetic waves is the most established one.

Section 2 of this paper gives a general overview of the WPT methods based on induction methods. Section 3 presents the concept of inductive coupling and illustrates the circuit models for biomedical WPT applications. Section 4 provides the comparison list of the research works that are summarized in a tabular format in the Appendix. Power efficiency $(\eta)$ and optimization methods that are achieved in researcher publications are summarized too. Section 5 provides the conclusions.

\section{A General Review on Wireless Power Transfer}

Nikola Tesla was the leader of WPT. In 1891, he successfully performed an experiment to energize a lamp using a pair of coils. Later, he successfully performed similar experiments on two hundred lamps and transmitted power to them over a 25-mile distance [3].

WPT can be categorized into two methods: near-field and far-field transmission. Table 1 shows a comparison between these two methods. In general, near-field power transfer 
TABLE 1: Comparison of WPT methods.

\begin{tabular}{lccccc}
\hline Method of WPT & Frequency & Directivity & Range & Penetration & $\eta$ \\
\hline Near field & Low Hz to MHz & Weak & Short & Strong \\
Far field & Medium MHz to THz & Medium to strong & Long & Medium to weak & Medium to low \\
\hline
\end{tabular}

methods have higher $\eta$ in comparison to the far-field ones. Most of the WPT applications are using the nearfield method. In order to consider any region to be near-field, two conditions should be considered: first, the distance between the transmitter and receiver coil $(r)$ should be less than one wavelength $(\lambda)$ at the operating frequency $(r<\lambda)$, and secondly, the largest dimension of the transmitter coil should be less than $\lambda / 2$. For implantable biomedical device applications based on far-field transfer, a good review may be found in [4]. The far-field methods are based on delivering power to a device using antennas. In this paper, the focus is on the applications of near-field power transfer methods.

Most biomedical near-field WPT methods use operating frequencies within the range of $100 \mathrm{kHz}$ to $50 \mathrm{MHz}$. Comparing the wavelength at this range with the typical transmission, which is between $1 \mathrm{~cm}$ and $11 \mathrm{~cm}$, the corresponding $\lambda$ of the electromagnetic field is relatively long. Therefore, the transfer can be viewed as a near-field progress [5]. There are three major ways to accomplish a near-field WPT: (1) capacitive coupling based on electric fields, (2) inductive coupling based on magnetic fields, and (3) magnetic resonant inductive coupling.

WPT by inductive coupling and resonant coupling is the main alternative to power implantable devices [6]. The survey provided in this paper is mainly focused on the studies that considered an inductive method to deliver power wirelessly to biomedical devices.

The first reported use of inductive power transfer (IPT) was in the 1960s [7]. This paper introduced IPT to transfer power to an artificial heart. Since then, many implantable devices have used similar methods for power transfer. In the 1970s, IPT was used in other biomedical applications [2, 8-16].

In the late 1970s, IPT was used to transfer high levels of power. Some projects were launched in the 1980s, but they were unsuccessful due to the rating of semiconductor devices used in the power supply that limited the use of high frequencies and $\eta$ [17]. In the mid-1990s, IPT was successfully commercialized in many applications [18]. Nowadays, the WPT based on IPT is still developing in many areas. This paper concentrates on biomedical applications.

\section{Inductive Coupling Concept and Wireless Power Transfer Models for Biomedical Devices}

An IPT system consists of two coils referred to as the "primary" and "secondary" coils. Figure 1 shows the system model. Power transfer occurs when a primary source

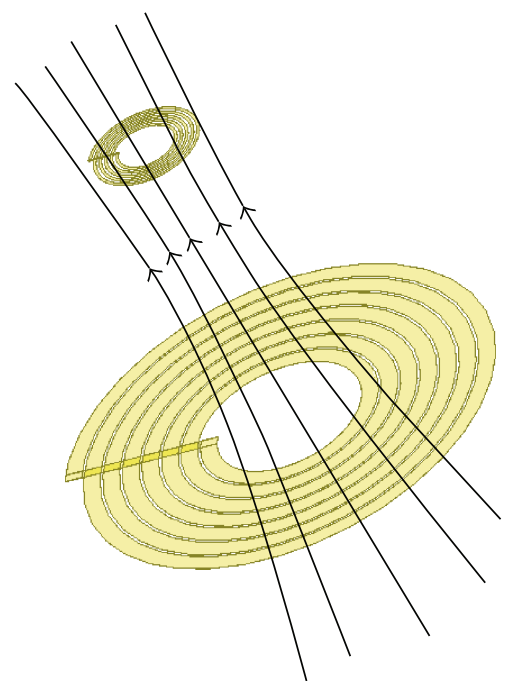

FIGURE 1: Inductive coupling principle.

generates magnetic and electric fields, $\overrightarrow{\mathbf{H}}$ and $\overrightarrow{\mathbf{E}}$, respectively, that induce voltage $V$ at the secondary receiver

$$
V=j \omega \mu \int \overrightarrow{\mathbf{H}} \cdot \overrightarrow{d s}
$$

where $\omega$ is the operating angular frequency and $\mu$ is the permeability of transfer medium. According to (1), coupling between coils mainly depends on the amount of magnetic flux linkage between the primary and secondary coils. Decreasing the distance between the primary transmitter and secondary receiver while increasing the length of the coils helps to increase the amount of magnetic flux. If the primary and secondary coils are not well aligned, efficiency $(\eta)$ will drop down causing more power loss.

A power transfer system block diagram for biomedical systems is shown in Figure 2. This system has three components; the first component is the power transmitter. The power transmitter is located outside the body. It may also be worn or placed in a distant location, for example, in a room under the floor, chair, or bed. The power transmitter circuit consists of DC source, a DC-AC converter (which enables transfer of power at the proposed operating frequency), a tuning circuit, a power antenna which allows the data connectivity to send data to the receiver and also as a feedback to receive information sending by the implanted device, and a primary power coil (which allows the power transfer). The second component is the power receiver which is implanted inside the body below the tissue or even patched on human skin. The receiver receives the wireless power and provides a stable energy to the load or use the energy to charge a battery. The receiver circuit consists of a secondary 


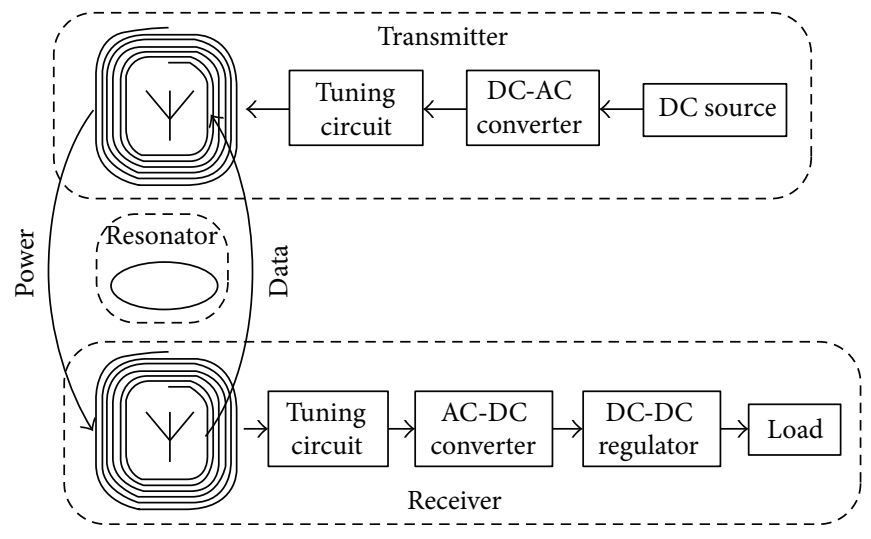

FIgUre 2: Model of WPT system for a biomedical device.

power antenna, a tuning circuit, an AC-DC converter, a DCDC converter (regulator), and a power management unit to interact with the transmitter through the implanted antenna. The third component is the middle power resonator. This component is used as a third part to resonate at the operating frequency and to help deliver power to farther distance places. It could also be worn or located at the receiver circuit under the human body. This component is not mandatory for all WPT system design.

The main goal to be achieved by any WPT design is to transfer power with high efficiency and power stability. There are five main challenges facing that. The first challenge is the transmitter's and receiver's size; as the receiver will be located inside the human body, its size will be limited. This small size will affect the quality factor and will decrease the coupling coefficient and $\eta$ accordingly. The second challenge is the operating frequency; as the operating frequency increases, $\eta$ will increase, but that will increase the energy loss in human tissue, which is causing increased heat that can be a safety issue. The third challenge is the ratio between the transfer distance and the antennas size. As the distance increases, $\eta$ decreases. The fourth factor is the lateral and angular misalignments between the transmitter and the receiver antennas, which cause degradation of the coupling factor and as a result, $\eta$ will decrease too. The fifth challenge is the required power level by the receiver. For low power level application, the main issue is how to transfer power with high $\eta$, since efficiency decreases as the power level decreases. On the other hand, the challenges for high power applications are to avoid the thermal issue at the transmitter coil side and how to keep the electromagnetic energy absorbed by the body tissues as low as possible.

\section{Prior Art}

Tables 2-4 present the collection of papers on this topic. These papers are focused on the research topics of wireless power transfer for biomedical applications. The papers are sorted in a descending order based on the year they were published. If two papers have the same year of publication, they are sorted based on operating frequency used in the methodology. The design criteria of these papers are as follows.
4.1. Size Optimization Method for Transmitter and Receiver. Optimization methods to determine the transmitter and receiver coil dimensions are used to increase the coupling coefficient and to determine the optimal frequency to improve $\eta$. Probably, one of the major challenges with biomedical wireless power transfer is the restrictions on the size of devices. The devices are implanted in layers of body tissue. The maximum size may lay between a few to tens of millimeters. The receiver is usually in a small packaging. As an example, capsule endoscopy is taken orally. The size of this capsule is between $11 \mathrm{~mm}$ to $27 \mathrm{~mm}$ in general applications [5]. The optimum antenna shape and dimensions for both the transmitter and receiver should be predicted based on optimum operating frequency and the gap range that is needed to power it.

Basic optimization for transmitter coil could be performed in two ways which most of the collected paper started with. The first one considers that the transfer distance is known ( $x$ is fixed and constant). This method is suitable for medical applications where the device is implanted in a certain place under the skin and within tissue layers. Based on that, the optimum transmitter coil radius (a) is calculated using (2). This equation is derived by calculating the maximum generated $\overrightarrow{\mathbf{H}}$ field by the transmitter coil at certain distance [5].

$$
a=\sqrt{2} x .
$$

The second optimization method is presented for those applications having portable or nonfixed receivers, with predicted range such as capsule endoscopy. Transmitter coil radius is optimized by calculating the integration of $\overrightarrow{\mathbf{H}}(\Psi)$ within the transfer range $(x)$ [5], based on the following:

$$
\Psi=\int_{x 1}^{x 2} \overrightarrow{\mathbf{H}} \cdot \overrightarrow{d x}=\int_{x 1}^{x 2} \frac{I N a^{2}}{2 \sqrt{\left(a^{2}+x^{2}\right)^{3}}} d x,
$$

where $I$ is the coil current in ampere and $N$ is the number of coil turns. One example of the capsule endoscope is modeled on $\mathrm{Matlab}^{\circledR}$ to determine the optimum coil radius for a range of distance between the centers of transmitter coil and the capsule endoscope $(x 1-x 2)$ that varies within $0-10 \mathrm{~cm}$, in 
TABLE 2: Implantable power device modeled in tissue.

\begin{tabular}{|c|c|c|c|c|c|c|c|c|c|c|}
\hline Ref & Journal & Year & Frequency & $\begin{array}{l}\text { Output } \\
\text { power } \\
(\mathrm{mW})\end{array}$ & $\begin{array}{l}\text { Optimization } \\
\text { method for } \\
\text { inductor } \\
\text { dimension }\end{array}$ & $\begin{array}{l}\text { Transmitter } \\
\text { dimension } \\
(\mathrm{mm})\end{array}$ & $\begin{array}{c}\text { Receiver } \\
\text { dimension } \\
{[\mathrm{mm}]}\end{array}$ & $\begin{array}{l}\text { Gap } \\
(\mathrm{mm})\end{array}$ & $\eta(\%)$ & Simulation model \\
\hline [29] & $\begin{array}{l}\text { IEEE Antennas } \\
\text { and Wireless } \\
\text { Propagation } \\
\text { Letters }\end{array}$ & 2017 & $\begin{array}{l}13.56 \mathrm{MHz} \\
\text { (power) } \\
\text { and } \\
910 \mathrm{MHz} \\
\text { (data) }\end{array}$ & & $\begin{array}{c}\text { Frequency } \\
\text { domain solver } \\
\text { in CST MWS }\end{array}$ & $\begin{array}{c}d_{\text {outT }}=83.2 \\
d_{\text {inT }}=59.6 \\
\text { Circular } \\
\text { (CST MWS) }\end{array}$ & $\begin{array}{c}d_{\text {outT }}=24.2 \\
d_{\text {inT }}=19.2 \\
\text { Circular } \\
\text { (CST MWS) }\end{array}$ & 16 & $\begin{array}{l}17 \% \\
\text { for } \\
\text { power } \\
\text { link }\end{array}$ & $\begin{array}{l}2 \mathrm{~mm} \text { skin, } 2 \mathrm{~mm} \\
\text { fat, } 7 \mathrm{~mm} \text { bone, } \\
50 \mathrm{~mm} \text { tissue }\end{array}$ \\
\hline$[30]$ & $\begin{array}{c}\text { IEEE } \\
\text { Transactions } \\
\text { on Power } \\
\text { Electronics }\end{array}$ & 2015 & $800 \mathrm{KHz}$ & $30 \mathrm{e} 3$ & $\begin{array}{c}\text { Based on the } \\
\text { method in } \\
{[31]}\end{array}$ & $\begin{array}{c}d_{\text {out T }}=70 \\
d_{\text {inT }}=34 \\
\text { Circular litz } \\
\text { wire } \\
\text { Finite } \\
\text { element }(\mathrm{FE})\end{array}$ & $\begin{array}{c}d_{\text {outR }}=70 \\
d_{\text {inR }}=34 \\
\text { Circular litz } \\
\text { wire (FE) }\end{array}$ & 20 & 95 & $\begin{array}{l}\text { One layer of skin } \\
\text { (performed its } \\
\text { effect on } \\
\text { simulation) }\end{array}$ \\
\hline [32] & $\begin{array}{c}\text { IEEE } \\
\text { Transactions } \\
\text { on Biomedical } \\
\text { Circuits and } \\
\text { Systems }\end{array}$ & 2015 & $200 \mathrm{MHz}$ & 0.224 & $\begin{array}{c}\text { Follow flow } \\
\text { chart in the } \\
\text { paper }\end{array}$ & $\begin{array}{l}d_{\text {outT }}=24 \\
\text { Printed } \\
\text { hexagon } \\
\text { (HFSS) }\end{array}$ & $\begin{array}{c}d_{\text {outR }}=1 \\
\text { Wire wound } \\
(\text { HFSS })\end{array}$ & 12 & 0.56 & $\begin{array}{c}\text { Design was } \\
\text { wrapped with a } \\
10 \mathrm{~mm} \text { thick layer } \\
\text { of beef }\end{array}$ \\
\hline [23] & Sensors & 2014 & $13.56 \mathrm{MHz}$ & 150 & $\begin{array}{c}\text { Based on the } \\
\text { method in } \\
{[24]}\end{array}$ & $\begin{array}{c}d_{\text {out T }}=56 \\
d_{\text {inT }}=10 \\
\text { Printed spiral } \\
\text { (Matlab, } \\
\text { HFSS, FE \& } \\
\text { SEMCAD) }\end{array}$ & $\begin{array}{c}d_{\text {outR }}=11.6 \\
d_{\text {inR }}=0.5 \\
\text { Printed spiral } \\
\text { (Matlab, } \\
\text { HFSS, FE \& } \\
\text { SEMCAD) }\end{array}$ & 6 & $\begin{array}{c}32 \text { to } \\
80\end{array}$ & $\begin{array}{l}\text { Three layers of } \\
70 \times 60 \times 6 \mathrm{~mm}^{3} \text {, } \\
1 \mathrm{~mm} \text { skin, } 2 \mathrm{~mm} \\
\text { fat, } 3 \mathrm{~mm} \text { muscle }\end{array}$ \\
\hline [33] & $\begin{array}{c}\text { IEEE } \\
\text { Transactions } \\
\text { on Industrial } \\
\text { Electronics }\end{array}$ & 2014 & $8.1 \mathrm{MHz}$ & $29.8 \sim 93.3$ & $\begin{array}{l}\text { Optimization } \\
\text { has been done } \\
\text { only for } \\
\text { frequency }\end{array}$ & $\begin{array}{l}d_{\text {outT }}=30 \\
\text { Printed } \\
\text { square } \\
\text { (HFSS) }\end{array}$ & $\begin{array}{l}d_{\text {outR }}=20 \\
\text { Printed } \\
\text { square } \\
\text { (HFSS) }\end{array}$ & $12 \sim 20$ & $\begin{array}{l}47.6 \text { to } \\
65.4\end{array}$ & $\begin{array}{l}\text { Various types of } \\
\text { tissue including } \\
\text { blood }\end{array}$ \\
\hline [34] & $\begin{array}{l}\text { "European } \\
\text { Solid State } \\
\text { Circuit } \\
\text { Conference } \\
\text { (ESSCIRC)" }\end{array}$ & 2013 & $160 \mathrm{MHz}$ & $>183$ & $\begin{array}{c}\text { Based on the } \\
\text { method in } \\
{[35,36]}\end{array}$ & $\begin{array}{c}d_{\text {outT }}=14.5 \\
\text { Printed } \\
\text { square } \\
\text { (Momentum } \\
\text { EM \& HFSS) }\end{array}$ & $\begin{array}{c}d_{\text {outT }}=2.2 \\
\text { Printed } \\
\text { square } \\
\text { (Momentum } \\
\text { EM \& HFSS) }\end{array}$ & 10 & 0.8 & $\begin{array}{l}7.5 \mathrm{~mm} \text { of muscle } \\
\text { layer, } 2.5 \mathrm{~mm} \text { air }\end{array}$ \\
\hline [21] & $\begin{array}{c}\text { IEEE } \\
\text { Transactions } \\
\text { on Circuits and } \\
\text { Systems }\end{array}$ & 2013 & $13.56 \mathrm{MHz}$ & 10 & $\begin{array}{l}\text { Based on the } \\
\text { method in } \\
\text { [19] }\end{array}$ & $\begin{array}{c}60 \times 25 \\
\text { Printed } \\
\text { rectangle } \\
(\text { HFSS \& CST } \\
\text { EM })\end{array}$ & $\begin{array}{c}25 \times 10 \\
\text { Printed } \\
\text { rectangle } \\
(\text { HFSS \& CST } \\
\text { EM })\end{array}$ & $10 \sim 50$ & $\begin{array}{l}0.16 \text { to } \\
58.2\end{array}$ & $\begin{array}{c}\text { Receiver } \\
\text { sandwiched } \\
\text { between two layers } \\
\text { of pork tissues }\end{array}$ \\
\hline [36] & $\begin{array}{l}\text { IEEE Electron } \\
\text { Device Letters }\end{array}$ & 2013 & $6.78 \mathrm{MHz}$ & 10 & $\begin{array}{l}\text { Based on the } \\
\text { method in } \\
\text { [37] }\end{array}$ & $\begin{array}{l}d_{\text {outT }}=20 \\
\text { Printed } \\
\text { square } \\
\text { (HFSS) }\end{array}$ & $\begin{array}{l}d_{\text {outT }}=4.5 \\
\text { Printed } \\
\text { square } \\
\text { (HFSS) }\end{array}$ & $\begin{array}{l}5 \text { and } \\
12\end{array}$ & $\begin{array}{c}30 \text { and } \\
4.3\end{array}$ & $\begin{array}{c}\text { One layer of muscle } \\
\text { tissue }\end{array}$ \\
\hline [38] & $\begin{array}{c}\text { IEEE } \\
\text { Transactions } \\
\text { on Biomedical } \\
\text { Circuit and } \\
\text { Systems }\end{array}$ & 2009 & $13.56 \mathrm{MHz}$ & & $\begin{array}{l}\text { Based on the } \\
\text { method in } \\
\text { [19] }\end{array}$ & $\begin{array}{c}d_{\text {out T }}=24 \\
d_{\text {inT }}=9.4 \\
\text { Printed } \\
\text { square } \\
\text { (HFSS) }\end{array}$ & $\begin{array}{c}d_{\text {outR }}=10 \\
d_{\text {inR }}=7.2 \\
\text { Printed } \\
\text { square } \\
\text { (HFSS) }\end{array}$ & 10 & 30.84 & $\begin{array}{c}\text { Receiver } \\
\text { sandwiched } \\
\text { between two layers } \\
\text { of muscle }\end{array}$ \\
\hline [39] & $\begin{array}{c}\text { IEEE } \\
\text { Transactions } \\
\text { on Biomedical } \\
\text { Circuits and } \\
\text { Systems }\end{array}$ & 2007 & $6.785 \mathrm{MHz}$ & $1 \sim 10$ & $\begin{array}{c}\text { Follow flow } \\
\text { chart in the } \\
\text { paper }\end{array}$ & $\begin{array}{c}d_{\text {out } \mathrm{T}}=30 \\
\text { Circular litz } \\
\text { wire }\end{array}$ & $\begin{array}{c}d_{\text {outR }}=30 \\
\text { Circular litz } \\
\text { wire }\end{array}$ & $1 \sim 10$ & $\begin{array}{l}51 \text { to } \\
74\end{array}$ & One layer of skin \\
\hline$[40]$ & $\begin{array}{c}\text { IEEE } \\
\text { Transactions } \\
\text { on Circuits and } \\
\text { Systems }\end{array}$ & 2005 & $1 \mathrm{MHz}$ & 250 & $\begin{array}{l}\text { Coil effective } \\
\text { series } \\
\text { resistance } \\
\text { (ESR) } \\
\text { formulations }\end{array}$ & $\begin{array}{c}d_{\text {outT }}=40 \\
\text { Circular litz } \\
\quad \text { wire }\end{array}$ & $\begin{array}{c}d_{\text {out T }}=22 \\
\text { Circular litz } \\
\text { wire }\end{array}$ & 7 & 67 & $\begin{array}{l}\text { A tissue through } \\
\text { retinal prosthesis }\end{array}$ \\
\hline
\end{tabular}


TABLE 2: Continued.

\begin{tabular}{|c|c|c|c|c|c|c|c|c|c|c|}
\hline Ref & Journal & Year & Frequency & $\begin{array}{l}\text { Output } \\
\text { power } \\
(\mathrm{mW})\end{array}$ & $\begin{array}{l}\text { Optimization } \\
\text { method for } \\
\text { inductor } \\
\text { dimension }\end{array}$ & $\begin{array}{c}\text { Transmitter } \\
\text { dimension } \\
(\mathrm{mm})\end{array}$ & $\begin{array}{c}\text { Receiver } \\
\text { dimension } \\
{[\mathrm{mm}]}\end{array}$ & $\begin{array}{l}\text { Gap } \\
(\mathrm{mm})\end{array}$ & $\eta(\%)$ & Simulation model \\
\hline$[41]$ & $\begin{array}{c}\text { IEEE } \\
\text { Transactions } \\
\text { on Circuits and } \\
\text { Systems }\end{array}$ & 2005 & $1 \mathrm{MHz}$ & $>250$ & & $\begin{array}{c}d_{\text {out T }}=40 \\
d_{\text {inT }}=32 \\
\text { Disk }\end{array}$ & $\begin{array}{c}d_{\text {outR }}=22 \\
d_{\text {inR }}=18 \\
\text { Disk }\end{array}$ & $\begin{array}{l}7 \text { and } \\
15\end{array}$ & $\begin{array}{l}33.3 \text { to } \\
65.8\end{array}$ & $\begin{array}{l}\text { A tissue through } \\
\text { retinal prosthesis }\end{array}$ \\
\hline [42] & $\begin{array}{l}\text { ELSEVIER } \\
\text { Sensors and } \\
\text { Actuators }\end{array}$ & 2004 & $700 \mathrm{KHz}$ & 50 & $\begin{array}{c}\text { Using a self- } \\
\text { developed } \\
\text { design tool } \\
\text { and equations }\end{array}$ & $\begin{array}{c}d_{\text {outT }}=60 \\
\text { Pancake/disk } \\
\text { (FastHenry } \\
\text { and Matlab) }\end{array}$ & $\begin{array}{c}d_{\text {outR }}=20 \\
\text { Solenoid } \\
\text { (FastHenry } \\
\text { and Matlab) }\end{array}$ & 30 & 36 & One layer of skin \\
\hline
\end{tabular}

steps of $1 \mathrm{~cm}$. Figure 3 shows the results. For example, the optimized transmitter radius for the transfer range from $2 \mathrm{~cm}$ to $10 \mathrm{~cm}$ is $7 \mathrm{~cm}$.

The sixth columns of Tables 2-4 indicate the optimization method that each paper performed. The methods presented in $[19,20]$ use custom-made methods for geometry optimization. Methods presented in [21, 22] are based on the optimization method described in [19]. This optimization method is used when the operating frequency of the design is known. This method applies five steps for optimizing the dimensions of the transmitter and receiver antenna. The first step is to apply the design constraints for the receiver. The second step is to set the initial values for coil dimensions based on manufacturing limitation and optimum transmitter coil dimension described at the beginning of this section. The third step is to optimize the size and fill factor for the transmitter coil. The fourth step is to set the line width and fill factor for the receiver coil side. The fifth step is to return back and reset the size and line width of the transmitter side. After that, iterations are going until the value of the required tolerance of the $\eta$ value is achieved.

The work in [23] follows Harrison's method to optimize the coil size [24]. Harrison's method is used for designing planar spiral pancake-shape coils. He concluded that the maximum $\eta$ could be achieved by considering $d_{\mathrm{inT}}=0.18$ $d_{\text {out T }}$ and $d_{\text {inR }}=0.75 d_{\text {outR }}$, where $d_{\text {inT }}$ is the inner transmitter diameter, $d_{\text {out T }}$ is the outer transmitter diameter, $d_{\mathrm{inR}}$ is the inner receiver diameter, and $d_{\text {outR }}$ is the outer receiver diameter. The paper results are based on derived equations and an experimental study, which was conducted using multiple coils and their dimensions at maximum achieved $\eta$.

Reported research in $[25,26]$ did not include any optimization process to calculate the geometries of coils.

4.2. Circuit Model and Efficiency Calculation. The simplified schematic model circuit of the resonant coupling inductive link is shown in Figure 4. $L_{1}, R_{1}$, and $C_{\mathrm{p} 1}$ are the self-inductance, resistance, and capacitance of the transmitter coil, respectively. $L_{2}, R_{2}$, and $C_{\mathrm{p} 2}$ are the self-inductance, resistance, and capacitance of the receiver coil, respectively. $R_{\mathrm{L}}$ is the load resistance. $C_{\mathrm{S} 1}$ and $C_{\mathrm{S} 2}$ are the added capacitance on the transmitter and receiver part, respectively. The highest voltage gain and efficiency $(\eta)$ could be achieved when both inductors $\left(L_{1}\right.$ and $\left.L_{2}\right)$ and total equivalent capacitors $\left(C_{1}\right.$ and $\left.C_{2}\right)$ from the transmitter and receiver are tuned at the operating frequency according to the following:

$$
\omega_{0}=\frac{1}{\sqrt{L_{1} C_{1}}}=\frac{1}{\sqrt{L_{2} C_{2}}},
$$

where $C_{1} \approx C_{\mathrm{S} 1}$ and $C_{2} \approx C_{\mathrm{S} 2}+C_{\mathrm{p} 2}$; the delivered power to primary LC tank is divided between the transmitter coil resistance $\left(R_{1}\right)$, and the secondary load $\left(R_{\mathrm{L}}\right)$. The primary resistance converts the power to heat, and the power is transferred into the secondary coil through their mutual inductance $(M) . M$ is related to the coupling coefficient $k$ according to the following:

$$
k=\frac{M}{\sqrt{L_{1} L_{2}}} .
$$

The quality factors for the transmitter $\left(Q_{1}\right)$, receiver $\left(Q_{2}\right)$, and load $\left(Q_{L}\right)$ circuit are calculated as follows:

$$
\begin{aligned}
Q_{1} & =\frac{\omega_{0} L_{1}}{R_{1}}, \\
Q_{2} & =\frac{\omega_{0} L_{2}}{R_{2}}, \\
Q_{\mathrm{L}} & =\frac{R_{\mathrm{L}}}{\omega_{0} L_{2}} .
\end{aligned}
$$

The total AC-AC efficiency $(\eta)$ is calculated according to the following:

$$
\eta=\frac{k^{2} Q_{1} Q_{2}}{1+k^{2} Q_{1} Q_{2}+\left(Q_{2} / Q_{L}\right)} \times \frac{1}{1+\left(Q_{L} / Q_{2}\right)} .
$$

Consequently, maximum achievable efficiency $\left(\eta_{\max }\right)$ is given by

$$
\eta_{\max }=\frac{k^{2} Q_{1} Q_{2}}{\left(1+\sqrt{1+k^{2}} Q_{1} Q_{2}\right)^{2}} .
$$

Details of derivation of (7) and (8) can be found in [27]. The efficiency of DC-DC depends mostly on the efficiency of converters and is calculated as the product of $\eta$ and the converter efficiency. 
TABLe 3: Implantable power device modeled in air.

\begin{tabular}{|c|c|c|c|c|c|c|c|c|c|c|}
\hline Ref & Journal & Year & Frequency & $\begin{array}{l}\text { Output } \\
\text { power } \\
(\mathrm{mW})\end{array}$ & $\begin{array}{l}\text { Optimization } \\
\text { method for } \\
\text { the inductor } \\
\text { dimension }\end{array}$ & $\begin{array}{l}\text { Transmitter } \\
\text { dimension } \\
(\mathrm{mm})\end{array}$ & $\begin{array}{l}\text { Receiver } \\
\text { dimension } \\
(\mathrm{mm})\end{array}$ & $\begin{array}{l}\text { Gap } \\
(\mathrm{mm})\end{array}$ & $\eta(\%)$ & $\begin{array}{l}\text { Simulation } \\
\text { model }\end{array}$ \\
\hline [32] & $\begin{array}{c}\text { IEEE } \\
\text { Transactions } \\
\text { on Biomedical } \\
\text { Circuits and } \\
\text { Systems }\end{array}$ & 2015 & $200 \mathrm{MHz}$ & 0.224 & $\begin{array}{c}\text { Follow flow } \\
\text { chart in the } \\
\text { paper }\end{array}$ & $\begin{array}{l}d_{\text {outT }}=24 \\
\text { Printed } \\
\text { hexagonal } \\
\text { (HFSS) }\end{array}$ & $\begin{array}{c}d_{\text {outR }}=1 \\
\text { Wire wound } \\
\quad(\text { HFSS })\end{array}$ & 12 & 1.02 & Air \\
\hline [34] & $\begin{array}{c}\text { "European Solid } \\
\text { State Circuit } \\
\text { Conference } \\
\text { (ESSCIRC)" }\end{array}$ & 2013 & $160 \mathrm{MHz}$ & $>183$ & $\begin{array}{l}\text { Based on } \\
\text { the method } \\
\text { in }[35,36]\end{array}$ & $\begin{array}{c}d_{\text {outT }}=14.5 \\
\text { Printed square } \\
\text { (Momentum } \\
\text { EM \& HFSS) }\end{array}$ & $\begin{array}{c}d_{\text {outT }}=2.2 \\
\text { Printed square } \\
\text { (Momentum } \\
\text { EM \& HFSS) }\end{array}$ & 10 & 1.5 & Air \\
\hline [43] & $\begin{array}{l}\text { Hindawi: Active } \\
\text { and Passive } \\
\text { Electronic } \\
\text { Components }\end{array}$ & 2012 & $211.9 \mathrm{KHz}$ & 125 & $\begin{array}{l}\text { Based on } \\
\text { the method } \\
\text { in [42] }\end{array}$ & & & 10 & 12.5 & Air \\
\hline [44] & $\begin{array}{l}\text { "Proceedings } \\
\text { of the Annual } \\
\text { International } \\
\text { Conference } \\
\text { of the IEEE } \\
\text { Engineering in } \\
\text { Medicine and } \\
\text { Biology Society, } \\
\text { EMBS" }\end{array}$ & 2011 & $13.56 \mathrm{MHz}$ & 27 & $\begin{array}{l}\text { Based on } \\
\text { the method } \\
\text { in [19] }\end{array}$ & $\begin{array}{c}d_{\text {out T }}=27 \\
d_{\text {inT }}=11 \\
\text { Printed spiral }\end{array}$ & $\begin{array}{c}12 \times 10 \\
\text { Rectangle } \\
\text { Wire wound litz }\end{array}$ & 7 & & $\begin{array}{c}\text { Air, worn } \\
\text { as a jacket } \\
\text { on back of } \\
\text { a rat }\end{array}$ \\
\hline \multirow{3}{*}{ [45] } & \multirow{3}{*}{$\begin{array}{c}\text { IEEE } \\
\text { Transactions } \\
\text { on Biomedical } \\
\text { Circuits and } \\
\text { Systems }\end{array}$} & \multirow{3}{*}{2011} & \multirow{3}{*}{$13.56 \mathrm{MHz}$} & 49.5 & \multirow{3}{*}{$\begin{array}{c}\text { Follow } \\
\text { flow chart } \\
\text { in the paper }\end{array}$} & $\begin{array}{c}2 \text { coil } \\
d_{\text {out } \mathrm{T}}=37 \\
\text { Printed spiral } \\
(\text { HFSS })\end{array}$ & $\begin{array}{c}2 \text { coil } \\
d_{\text {outR }}=10 \\
\text { Printed spiral } \\
\text { (HFSS })\end{array}$ & & 75.7 & \multirow{3}{*}{ Air } \\
\hline & & & & 43.4 & & $\begin{array}{c}3 \text { coil } \\
d_{\text {out } \mathrm{T}}=43 \\
\text { Printed spiral } \\
(\text { HFSS })\end{array}$ & $\begin{array}{c}3 \text { coil } \\
d_{\text {outR }}=10 \\
\text { Printed spiral } \\
\text { (HFSS) }\end{array}$ & 10 & $\begin{array}{c}78.6 \\
3 \text { coil }\end{array}$ & \\
\hline & & & & 3.9 & & $\begin{array}{c}4 \text { coil } \\
d_{\text {out } \mathrm{T}}=36.5 \\
\text { Printed spiral } \\
(\mathrm{HFSS})\end{array}$ & $\begin{array}{c}4 \text { coil } \\
d_{\text {outR }}=10 \\
\text { Printed spiral } \\
(\text { HFSS })\end{array}$ & & $\begin{array}{c}83.5 \\
4 \text { coil }\end{array}$ & \\
\hline [25] & $\begin{array}{l}\text { ELSEVIER: } \\
\text { Procedia } \\
\text { Engineering }\end{array}$ & 2011 & $1 \mathrm{MHz}$ & 380 & & $\begin{array}{c}\text { Area }=1000 \mathrm{~mm}^{2} \\
\text { Spiral litz wire }\end{array}$ & $\begin{array}{c}\text { Area }=520 \mathrm{~mm}^{2} \\
\text { Spiral litz wire }\end{array}$ & 10 & 50 & Air \\
\hline$[20]$ & $\begin{array}{c}\text { IEEE } \\
\text { Transactions } \\
\text { on Bio Circuits } \\
\text { and Systems }\end{array}$ & 2011 & $700 \mathrm{KHz}$ & 100 & $\begin{array}{c}\text { Follow flow } \\
\text { chart in the } \\
\text { paper }\end{array}$ & $\begin{array}{c}d_{\text {out T }}=64 \\
\text { Spiral litz wire } \\
\quad(\text { Spice })\end{array}$ & $\begin{array}{c}d_{\text {outR }}=22 \\
\text { Spiral litz wire } \\
\quad(\text { Spice })\end{array}$ & 20 & 82 & Air \\
\hline [46] & $\begin{array}{c}\text { "2010 } 3^{\text {rd }} \\
\text { International } \\
\text { Symposium } \\
\text { on Applied } \\
\text { Science in } \\
\text { Biomedical and } \\
\text { Communication } \\
\text { Technology" }\end{array}$ & 2010 & $27 \mathrm{MHz}$ & 794 & $\begin{array}{c}\text { Coil built } \\
\text { based on } \\
\text { [47], no } \\
\text { optimization } \\
\text { used }\end{array}$ & & $\begin{array}{c}d_{\text {outR }}=15 \\
\text { Square (CST } \\
\text { MWS) }\end{array}$ & 15 & 80 & Air \\
\hline$[48]$ & $\begin{array}{c}\text { IEEE } \\
\text { Transactions } \\
\text { on Circuits } \\
\text { and Systems }\end{array}$ & 2010 & $13.56 \mathrm{MHz}$ & 11.2 & $\begin{array}{l}\text { Based on } \\
\text { the method } \\
\text { in [19] }\end{array}$ & $\begin{array}{c}d_{\text {out } \mathrm{T}}=20 \\
d_{\text {inT }}=10 \\
\text { Printed square }\end{array}$ & $\begin{aligned} & d_{\text {outR }}=10 \\
& d_{\text {inR }}=6 \\
& \text { Printed square }\end{aligned}$ & $5 \sim 20$ & $\begin{array}{l}1 \text { to } \\
14.1\end{array}$ & Air \\
\hline
\end{tabular}


TABle 3: Continued.

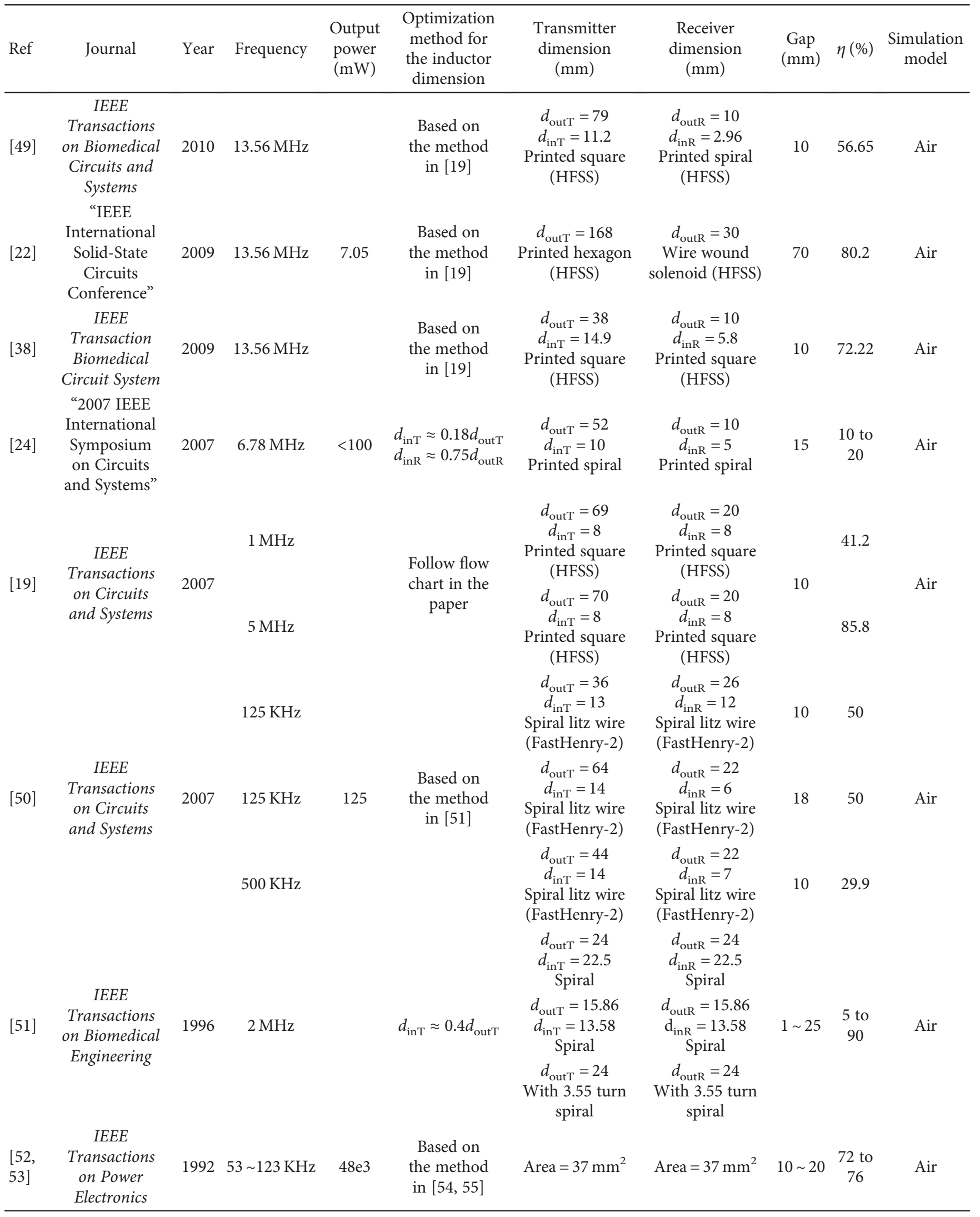


TABLE 4: Other model of implantable power device.

\begin{tabular}{|c|c|c|c|c|c|c|c|c|c|c|}
\hline Ref & Journal & Year & Frequency & $\begin{array}{l}\text { Output } \\
\text { power } \\
(\mathrm{mW})\end{array}$ & $\begin{array}{l}\text { Optimization } \\
\text { method for } \\
\text { inductor } \\
\text { dimensions }\end{array}$ & $\begin{array}{l}\text { Transmitter } \\
\text { dimension } \\
\left(\mathrm{mm}^{2}\right)\end{array}$ & $\begin{array}{l}\text { Receiver } \\
\text { dimension } \\
\left(\mathrm{mm}^{2}\right)\end{array}$ & $\begin{array}{c}\text { Gap } \\
(\mathrm{mm})\end{array}$ & $\begin{array}{c}\eta \\
(\%)\end{array}$ & $\begin{array}{c}\text { Simulation } \\
\text { model }\end{array}$ \\
\hline [34] & $\begin{array}{c}\text { "European Solid } \\
\text { State Circuit } \\
\text { Conference } \\
\text { (ESSCIRC)" }\end{array}$ & 2013 & $160 \mathrm{MHz}$ & $>183$ & $\begin{array}{l}\text { Based on } \\
\text { the method } \\
\text { in }[35,36]\end{array}$ & $\begin{array}{c}d_{\text {outT }}=14.5 \\
\text { Printed square } \\
\text { (Momentum } \\
\text { EM \& HFSS) }\end{array}$ & $\begin{array}{c}d_{\text {outT }}=2.2 \\
\text { Printed square } \\
\text { (Momentum } \\
\text { EM \& HFSS) }\end{array}$ & 10 & 1 & $\begin{array}{c}7 \mathrm{~mm} \text { of } 0.2 \\
\text { molar } \mathrm{NaCl} \\
\text { layer and } 3 \mathrm{~mm} \\
\text { air }\end{array}$ \\
\hline$[56]$ & $\begin{array}{c}\text { IEEE Transactions } \\
\text { on Biomedical } \\
\text { Engineering }\end{array}$ & 2012 & $13.56 \mathrm{MHz}$ & 24 & $\begin{array}{l}\text { Based on } \\
\text { the method } \\
\text { in }[57,58]\end{array}$ & $\begin{array}{l}d_{\text {outT }}=480 \\
\text { Circular } \\
\text { Built under } \\
\quad \text { floor }\end{array}$ & $\begin{array}{c}\text { Capsule } \\
13 \times 27\end{array}$ & 1000 & 3.04 & $\begin{array}{l}\text { Endoscopic } \\
\text { capsule }\end{array}$ \\
\hline [26] & $\begin{array}{c}\text { ELSEVIER: } \\
\text { Procedia } \\
\text { Engineering }\end{array}$ & 2010 & & 300 & & & $\begin{array}{c}\text { Capsule } \\
16 \times 28\end{array}$ & $\begin{array}{l}\text { Free } \\
\text { move }\end{array}$ & & $\begin{array}{c}\text { Endoscopic } \\
\text { capsule }\end{array}$ \\
\hline [38] & $\begin{array}{c}\text { IEEE Transaction } \\
\text { Biomedical Circuit } \\
\text { System }\end{array}$ & 2009 & $13.56 \mathrm{MHz}$ & & $\begin{array}{l}\text { Based on the } \\
\text { method in [19] }\end{array}$ & $\begin{array}{c}d_{\text {out } \mathrm{T}}=30 \\
d_{\text {inT }}=11.1 \\
\text { Printed square } \\
\text { (HFSS) }\end{array}$ & $\begin{array}{c}d_{\text {outR }}=10 \\
d \mathrm{i}_{\mathrm{nR}}=5.5 \\
\text { Printed square } \\
\text { (HFSS) }\end{array}$ & 10 & 51.8 & $\begin{array}{l}\text { Receiver placed } \\
\text { between two } \\
\text { layers of saline } \\
\text { in }\end{array}$ \\
\hline
\end{tabular}

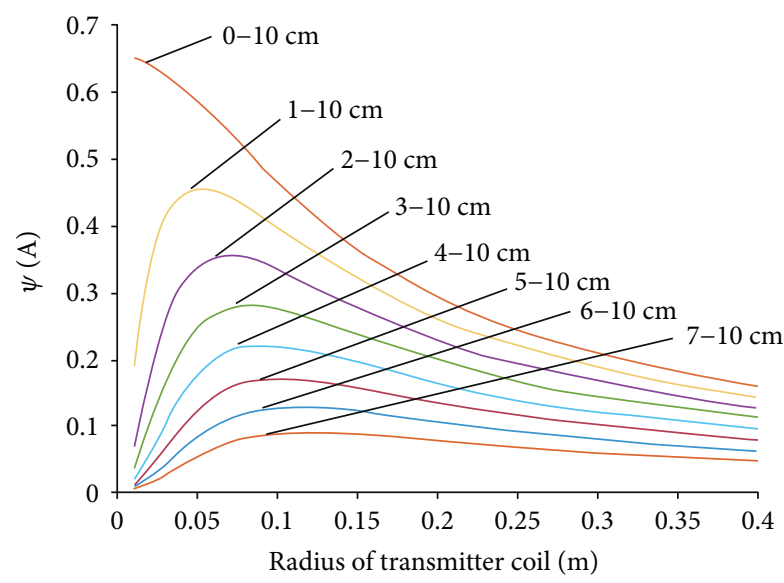

Figure 3: Magnetic field integration for specified transfer range.

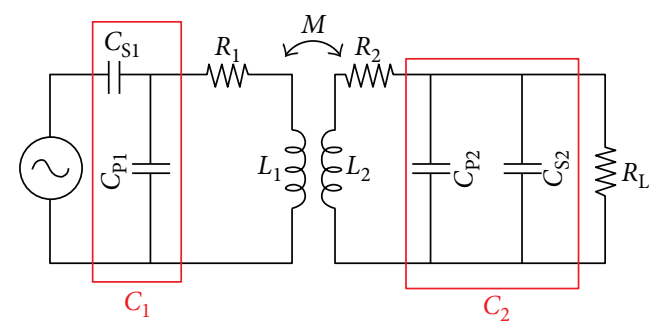

Figure 4: Circuit model of inductive coupling.

4.3. Summary of Achieved Performances. Figure 5 shows the efficiency versus the output or delivered power that the receiver collects from the transmitter for the papers listed in Tables 2, 3, and 4. It should be noted that the efficiency increases at high delivered power. However, various efficiencies may have been achieved for the same delivered power depending on the system design.

Figure 6 presents the graph of efficiency versus frequency. It is clear that the frequency for most of the biomedical

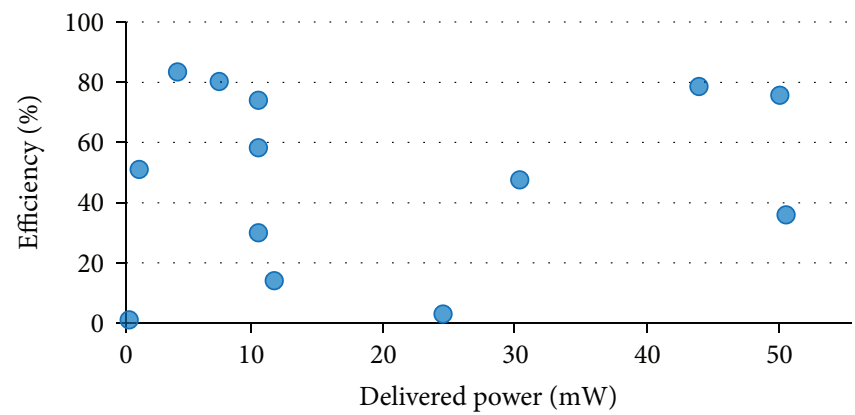

FIGURE 5: Efficiency versus delivered power.

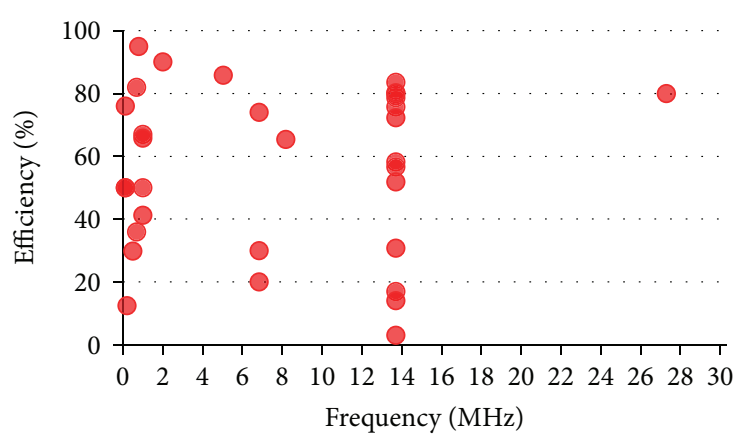

FIgURE 6: Efficiency versus frequency.

devices in the papers reviewed in this survey is below $50 \mathrm{MHz}$.

4.4. Future Directions. Nowadays, the focus is on miniaturizing implantable devices to reduce surgical complexity and infection risk. Electromagnetic energy transfer enables transcutaneous communication and powering with fully implantable wireless biomedical devices [28]. The main goal of WPT is to provide sufficient power to the implanted device while minimizing tissue heating due to the absorbed energy. This 
has led to an extensive research toward maximizing efficiency, through optimizing operating frequency, coils geometries, impedance matching, and power delivery.

The last columns of Tables 2-4 summarize the models that were considered as a medium surrounding the implanted device. Future directions for research also include addressing the effects of expected variations in the tissue medium and monitoring absorption in tissue to inform adjustments to transmit power, frequency, and impedance matching.

\section{Conclusion}

This paper presents a short survey of WPT based on IPT concept for biomedical applications. The delivered power to biomedical devices reported in the collected papers ranges from few $\mathrm{mW}$ to $48 \mathrm{~W}$, with maximum efficiency of up to $95 \%$ for $20 \mathrm{~mm}$ range.

\section{Appendix}

Table 2 presents the highlights of the research papers on the implanted power devices for medical applications that are modeled in tissue layers. Table 3 shows the highlights of the research on the implantable systems that are modeled in free space. Table 4 shows the highlights of the research that are in neither tissue layers nor air.

\section{Conflicts of Interest}

The authors declare that there is no conflict of interest regarding the publication of this paper.

\section{Acknowledgments}

This work was supported by the Electrical Engineering Department of University of North Dakota, the North Dakota Department of Commerce, and the Applied Science University in Jordan.

\section{References}

[1] J. S. Ho, S. Kim, and A. S. Y. Poon, "Midfield wireless powering for implantable systems," Proceedings of the IEEE, vol. 101, no. 6, pp. 1369-1378, 2013.

[2] M. Soma, D. C. Galbraith, and R. L. White, "Radio-frequency coils in implantable devices: misalignment analysis and design procedure," IEEE Transactions on Biomedical Engineering, vol. BME-34, no. 4, pp. 276-282, 1987.

[3] "The life and time of Nicola Tesla," http://www.comp.dit.ie/ dgordon/Research/MScArtefacts/Tesla/TeslaBook.pdf.

[4] C. Liu, Y. Guo, and S. Xiao, "A review of implantable antennas for wireless biomedical devices," Forum for Electromagnetic Research Methods and Application Technologies (FERMAT), vol. 14, 2016.

[5] T. Sun, X. Xie, and Z. Wang, Wireless Power Transfer for Medical Microsystems, Springer, New York, NY, USA, 2013.

[6] L. Baby and S. S. Banu, "A survey on wire free power transmission in biomedical implants," International Journal of Advanced Research in Electrical Electronics and Instrumentation Engineering, vol. 5, no. 5, pp. 3543-3546, 2016.

[7] J. C. Schuder, "Powering an artificial heart: birth of the inductively coupled-radio frequency system in 1960," Artificial Organs, vol. 26, no. 11, pp. 909-915, 2002.

[8] F. C. Flack, E. D. James, and D. M. Schlapp, "Mutual inductance of air-cored coils: effect on design of radio-frequency coupled implants," Medical and Biological Engineering, vol. 9, no. 2, pp. 79-85, 1971.

[9] J. C. Schuder, J. H. Gold, and H. E. Stephenson, "An inductively coupled RF system for the transmission of $1 \mathrm{~kW}$ of power through the skin," IEEE Transactions on Biomedical Engineering, vol. BME-18, no. 4, pp. 265-273, 1971.

[10] W. H. Ko, S. P. Liang, and C. D. F. Fung, "Design of radiofrequency powered coils for implant instruments," Medical and Biological Engineering and Computing, vol. 15, no. 6, pp. 634-640, 1977.

[11] N. d. N. Donaldson and T. A. Perkins, "Analysis of resonant coupled coils in the design of radio frequency transcutaneous links," Medical and Biological Engineering and Computing, vol. 21, no. 5, pp. 612-627, 1983.

[12] J. A. Von Arx and K. Najafi, "A wireless single-chip telemetrypowered neural stimulation system," in 1999 IEEE International Solid-State Circuits Conference. Digest of Technical Papers. ISSCC. First Edition (Cat. No.99CH36278), pp. 214215, San Francisco, CA, USA, 1999.

[13] W. J. Heetderks, "RF powering of millimeter- and submillimeter-sized neural prosthetic implants," IEEE Transactions on Biomedical Engineering, vol. 35, no. 5, pp. 323327, 1988.

[14] C. M. Zierhofer and E. S. Hochmair, "High-efficiency coupling-insensitive transcutaneous power and data transmission via an inductive link," IEEE Transactions on Biomedical Engineering, vol. 37, no. 7, pp. 716-722, 1990.

[15] K. Van Schuylenbergh and R. Puers, "Self tuning inductive powering for implantable telemetric monitoring systems," in Solid-State Sensors and Actuators, 1995 and Eurosensors IX. Transducers '95. The 8th International Conference on, vol. 1, pp. 1-7, Stockholm, Sweden, 1995.

[16] T. Akin, K. Najafi, and R. M. Bradley, "A wireless implantable multichannel digital neural recording system for a micromachined sieve electrode," IEEE Journal of Solid-State Circuits, vol. 33, no. 1, pp. 109-118, 1998.

[17] J. Dai and D. C. Ludois, “A survey of wireless power transfer and a critical comparison of inductive and capacitive coupling for small gap applications," IEEE Transactions on Power Electronics, vol. 30, no. 11, pp. 6017-6029, 2015.

[18] G. A. Covic and J. T. Boys, "Inductive power transfer," Proceedings of the IEEE, vol. 101, no. 6, pp. 1276-1289, 2013.

[19] U. M. Jow and M. Ghovanloo, "Design and optimization of printed spiral coils for efficient transcutaneous inductive power transmission," IEEE Transactions on Biomedical Circuits and Systems, vol. 1, no. 3, pp. 193-202, 2007.

[20] A. K. Ramrakhyani, S. Mirabbasi, and M. Chiao, "Design and optimization of resonance-based efficient wireless power delivery systems for biomedical implants," IEEE Transactions on Biomedical Circuits and Systems, vol. 5, no. 1, pp. 48-63, 2011.

[21] R. F. Xue, K. W. Cheng, and M. Je, "High-efficiency wireless power transfer for biomedical implants by optimal resonant load transformation," IEEE Transactions on Circuits and Systems I: Regular Papers, vol. 60, no. 4, pp. 867-874, 2013. 
[22] M. Yin and M. Ghovanloo, "A flexible clockless 32-ch simultaneous wireless neural recording system with adjustable resolution," in 2009 IEEE International Solid-State Circuits Conference - Digest of Technical Papers, pp. 432-434, San Francisco, CA, USA, 2009.

[23] S. Mutashar, M. Hannan, S. Samad, and A. Hussain, "Analysis and optimization of spiral circular inductive coupling link for bio-implanted applications on air and within human tissue," Sensors, vol. 14, no. 7, pp. 11522-11541, 2014.

[24] R. R. Harrison, "Designing efficient inductive power links for implantable devices," in 2007 IEEE International Symposium on Circuits and Systems, pp. 2080-2083, New Orleans, LA, USA, 2007.

[25] R. Carta, J. Thoné, G. Gosset, G. Cogels, D. Flandre, and R. Puers, "A self-tuning inductive powering system for biomedical implants," Procedia Engineering, vol. 25, pp. 15851588, 2011.

[26] R. Carta, N. Pateromichelakis, J. Thoné, M. Sfakiotakis, D. P. Tsakiris, and R. Puers, "A wireless powering system for a vibratory-actuated endoscopic capsule," Procedia Engineering, vol. 5, pp. 572-575, 2010.

[27] INTECH, Wireless Telemetry for Implantable Biomedical Microsystems, http://www.kntu.ac.ir/DorsaPax/userfiles/file/ Electrical/az-icas/20120716090651608.pdf.

[28] K. Bocan and E. Sejdić, "Adaptive transcutaneous power transfer to implantable devices: a state of the art review," Sensors, vol. 16, no. 3, p. 393, 2016.

[29] A. Sharma, E. Kampianakis, and M. S. Reynolds, "A dual-band HF and UHF antenna system for implanted neural recording and stimulation devices," IEEE Antennas and Wireless Propagation Letters, vol. 16, pp. 493-496, 2017.

[30] O. Knecht, R. Bosshard, and J. W. Kolar, "High-efficiency transcutaneous energy transfer for implantable mechanical heart support systems," IEEE Transactions on Power Electronics, vol. 30, no. 11, pp. 6221-6236, 2015.

[31] O. Knecht, R. Bosshard, J. W. Kolar, and C. T. Starck, "Optimization of transcutaneous energy transfer coils for high power medical applications," in 2014 IEEE 15th Workshop on Control and Modeling for Power Electronics (COMPEL), pp. 62216236, Santander, Spain, 2014.

[32] D. Ahn and M. Ghovanloo, "Optimal design of wireless power transmission links for millimeter-sized biomedical implants," IEEE Transactions on Biomedical Circuits and Systems, vol. 10, no. 1, pp. 125-137, 2016.

[33] D. Ahn and S. Hong, "Wireless power transmission with self-regulated output voltage for biomedical implant," IEEE Transactions on Industrial Electronics, vol. 61, no. 5, pp. 2225-2235, 2014.

[34] M. Zargham and P. G. Gulak, "A $0.13 \mu \mathrm{m}$ CMOS integrated wireless power receiver for biomedical applications," in 2013 Proceedings of the ESSCIRC (ESSCIRC), pp. 137140, Bucharest, Romania, 2013.

[35] M. Zargham and P. G. Gulak, "Maximum achievable efficiency in near-field coupled power-transfer systems," IEEE Transactions on Biomedical Circuits and Systems, vol. 6, no. 3, pp. 228-245, 2012.

[36] R. Wu, S. Raju, M. Chan, J. K. O. Sin, and C. P. Yue, "Siliconembedded receiving coil for high-efficiency wireless power transfer to implantable biomedical ICs," IEEE Electron Device Letters, vol. 34, no. 1, pp. 9-11, 2013.
[37] R. Wu, S. Raju, M. Chan, J. K. O. Sin, and C. P. Yue, "Wireless power link design using silicon-embedded inductors for brainmachine interface," in Proceedings of Technical Program of 2012 VLSI Design, Automation and Test, pp. 1-4, Hsinchu, Taiwan, 2012.

[38] U.-M. Jow and M. Ghovanloo, "Modeling and optimization of printed spiral coils in air, saline, and muscle tissue environments," IEEE Transactions on Biomedical Circuits and Systems, vol. 3, no. 5, pp. 339-347, 2009.

[39] M. W. Baker and R. Sarpeshkar, "Feedback analysis and design of RF power links for low-power bionic systems," IEEE Transactions on Biomedical Circuits and Systems, vol. 1, no. 1, pp. 28-38, 2007.

[40] G. A. Kendir, Wentai Liu, Guoxing Wang et al., "An optimal design methodology for inductive power link with class-E amplifier," IEEE Transactions on Circuits and Systems I Regular Papers, vol. 52, no. 5, pp. 857-866, 2005.

[41] G. Wang, W. Liu, M. Sivaprakasam, and G. A. Kendir, "Design and analysis of an adaptive transcutaneous power telemetry for biomedical implants," IEEE Transactions on Circuits and Systems I Regular Papers, vol. 52, no. 10, pp. 2109-2117, 2005.

[42] M. Catrysse, B. Hermans, and R. Puers, "An inductive power system with integrated bi-directional data-transmission," Sensors and Actuators A: Physical, vol. 115, no. 2-3, pp. 221229, 2004.

[43] M. A. Adeeb, A. B. Islam, M. R. Haider, F. S. Tulip, M. N. Ericson, and S. K. Islam, "An inductive link-based wireless power transfer system for biomedical applications," Active and Passive Electronic Components, vol. 2012, Article ID 879294, 11 pages, 2012.

[44] M. Kiani, K. Y. Kwon, F. Zhang, K. Oweiss, and M. Ghovanloo, "Evaluation of a closed loop inductive power transmission system on an awake behaving animal subject," in 2011 Annual International Conference of the IEEE Engineering in Medicine and Biology Society, pp. 7658-7661, Boston, MA, USA, 2011.

[45] M. Kiani, Uei-Ming Jow, and M. Ghovanloo, "Design and optimization of a 3-coil inductive link for efficient wireless power transmission," IEEE Transactions on Biomedical Circuits and Systems, vol. 5, no. 6, pp. 579-591, 2011.

[46] A. Laskovski and M. Yuce, "Class-E oscillators as wireless power transmitters for biomedical implants," in $20103 \mathrm{rd}$ International Symposium on Applied Sciences in Biomedical and Communication Technologies (ISABEL 2010), pp. 1-5, Roma, Italy, 2010.

[47] A. Laskovski, M. Yuce, and T. Dissanayake, "Stacked spirals for use in biomedical implants," in 2009 Asia Pacific Microwave Conference, pp. 389-392, Singapore, Singapore, 2009.

[48] M. Kiani and M. Ghovanloo, "An RFID-based closed-loop wireless power transmission system for biomedical applications," IEEE Transactions on Circuits and Systems II: Express Briefs, vol. 57, no. 4, pp. 260-264, 2010.

[49] U.-M. Jow and M. Ghovanloo, "Optimization of data coils in a multiband wireless link for neuroprosthetic implantable devices," IEEE Transactions on Biomedical Circuits and Systems, vol. 4, no. 5, pp. 301-310, 2010.

[50] M. Ghovanloo and S. Atluri, "A wide-band power-efficient inductive wireless link for implantable microelectronic devices using multiple carriers," IEEE Transactions on Circuits and Systems I: Regular Papers, vol. 54, no. 10, pp. 2211-2221, 2007.

[51] C. M. Zierhofer and E. S. Hochmair, "Geometric approach for coupling enhancement of magnetically coupled coils," IEEE 
Transactions on Biomedical Engineering, vol. 43, no. 7, pp. 708-714, 1996.

[52] A. Ghahary and B. H. Cho, "Design of transcutaneous energy transmission system using a series resonant converter," IEEE Transactions on Power Electronics, vol. 7, no. 2, pp. 261-269, 1992.

[53] G. B. Joun and B. H. Cho, "An energy transmission system for an artificial heart using leakage inductance compensation of transcutaneous transformer," IEEE Transactions on Power Electronics, vol. 13, no. 6, pp. 1013-1022, 1998.

[54] E. S. Hochmair, "System optimization for improved accuracy in transcutaneous signal and power transmission," IEEE Transactions on Biomedical Engineering, vol. BME-31, no. 2, pp. 177-186, 1984.

[55] A. Ghahary, Design of Transctaneous Energy Transmission System Using Series Resonant Converter, Univ. Verginia Power Electronic Center, 1989.

[56] T. Sun, X. Xie, G. Li, Y. Gu, Y. Deng, and Z. Wang, “A two-hop wireless power transfer system with an efficiency-enhanced power receiver for motion-free capsule endoscopy inspection," IEEE Transactions on Biomedical Engineering, vol. 59, no. 11, pp. 3247-3254, 2012.

[57] M. Ryu, J. D. Kim, H. U. Chin, J. Kim, and S. Y. Song, "Three-dimensional power receiver for in vivo robotic capsules," Medical \& Biological Engineering \& Computing, vol. 45, no. 10, pp. 997-1002, 2007.

[58] A. Kurs, A. Karalis, R. Moffatt, J. D. Joannopoulos, P. Fisher, and M. Soljacic, "Wireless power transfer via strongly coupled magnetic resonances," Science, vol. 317 , no. 5834, pp. 83-86, 2007. 


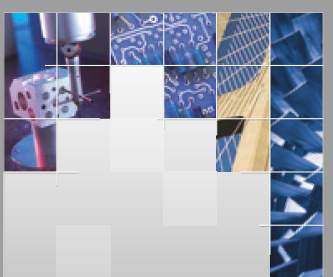

\section{Enfincering}
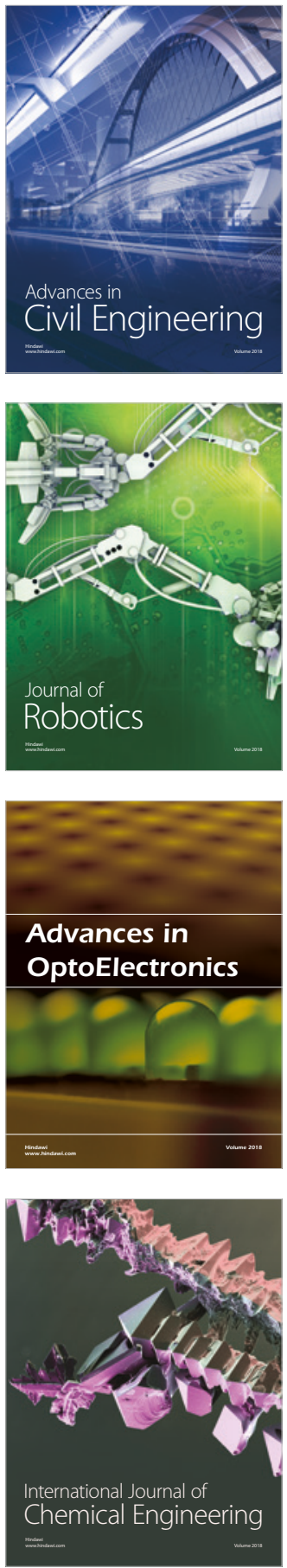

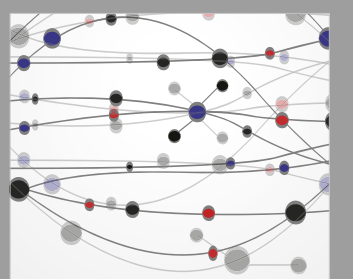

\section{Rotating \\ Machinery}

The Scientific World Journal

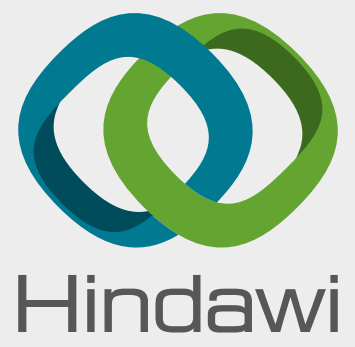

Submit your manuscripts at

www.hindawi.com
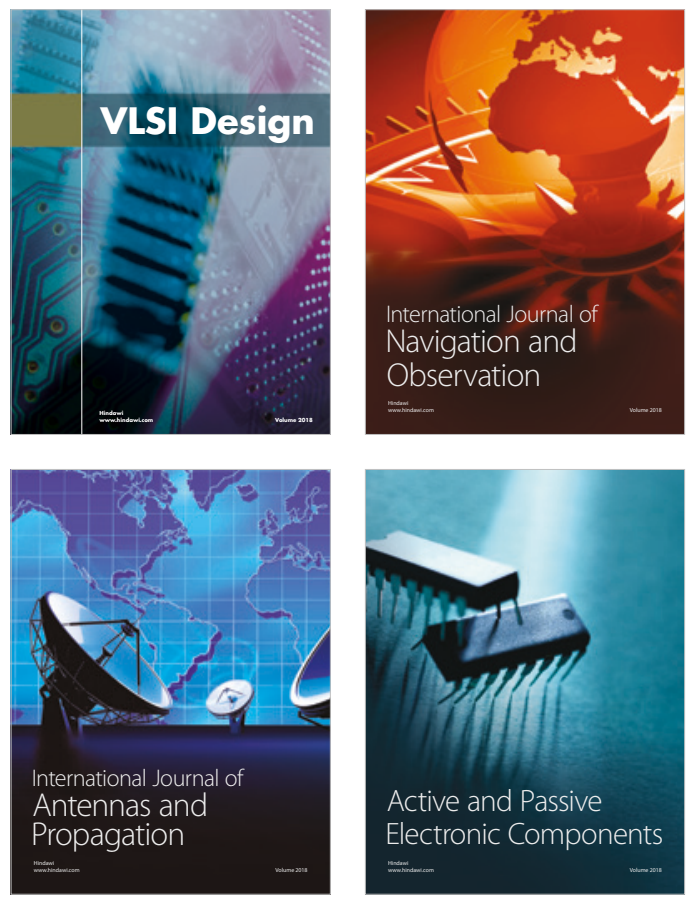
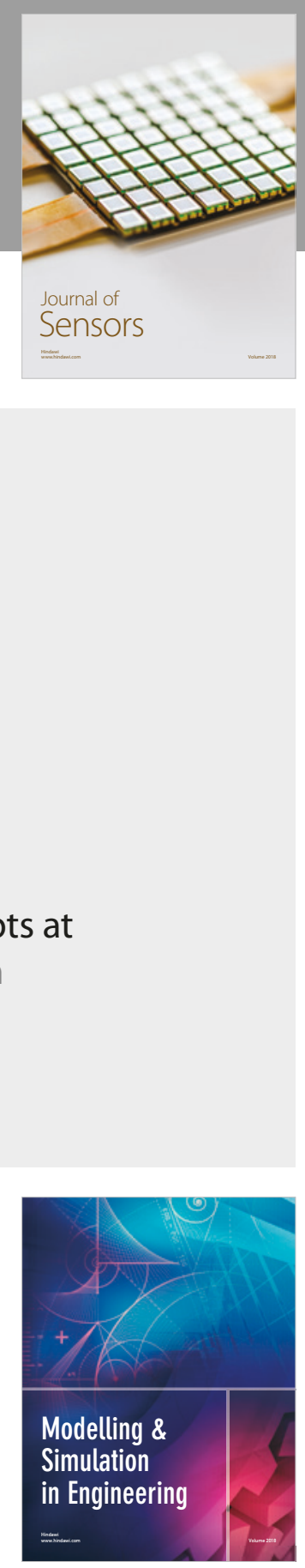

\section{Advances \\ Multimedia}
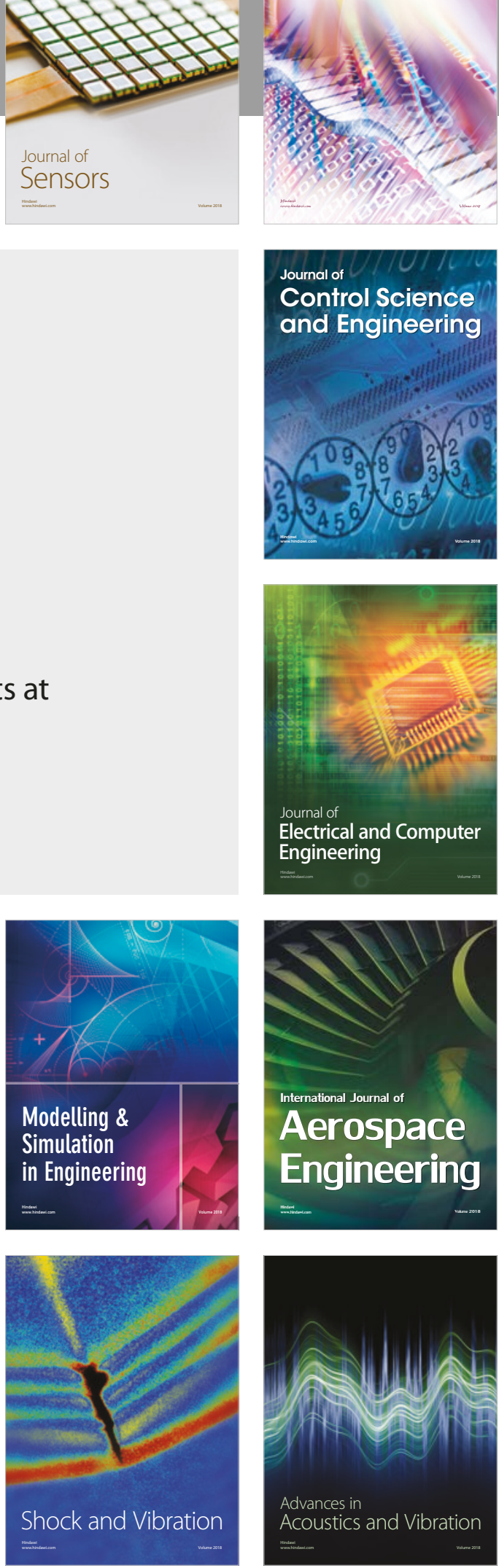